\title{
Diallel analysis in white lupin: consequences for breeding
}

\author{
L Le Sech *, C Huyghe \\ SAPF, INRA, 86600 Lusignan, France
}

(Received 21 December 1990; accepted 6 August 1991)

\begin{abstract}
Summary - A complete diallel analysis for several characters was conducted in spring type white lupins (Lupinus a/bus $L$ ). Each of the 7 parents represented a group of the genetic variability available in the Mediterranean area. An analysis of the genetic parameters for the different characters should be of help in the definition of optimum lupin breeding criteria. Both vegetative and reproductive characters were studied. Diallel analysis was carried out via 2 methods, ie those of Griffing and Hayman. As for most of the autogamous species, vegetative characters and seed size showed a mainly additive heredity with a limited amount of specific combining ability (SCA). Both broad and narrow sense heritabilities proved to be high. The correlations between general combining ability (GCA) and phenotypic values were high, which suggested that judgement of the phenotype could give a good estimate of behaviour in the cross. For pod setting characters, both heritabilities were lower likely because of a higher susceptibility to the environment and to larger dominance. A heterotic effect was observed for yield; this could be explained by the low cropping densities and the homeostatis ability of the hybrids. This kind of genetic structure appears to be a means of improving yield stability. Unfortunately, it is not possible at the present time because no male sterility is available. For pure line breeding, the general combining ability (GCA) values showed that Lublanc and LA123 appeared to be first-choice parents for improvement of earliness in flowering with a good pod setting, while Lucky was an interesting candidate for pod setting and seed size characters.
\end{abstract}

Lupinus albus $\mathrm{L}=$ white lupin / diallel / genetic analysis / plant breeding / yield component / earliness / morphology

Résumé - Étude diallèle sur le lupin blanc : conséquences en sélection. L'étude d'un diallèle complet de 7 génotypes de lupin blanc (Lupinus albus $L$ ) de type printemps a permis l'analyse génétique de nombreux caractères. Chacun des parents utilisés représente un groupe particulier au sein de la variabilité spécifique disponible sur le pourtour méditerranéen (tableau 1). L'analyse génétique de ces différents caractères doit permettre de définir les critères de sélection les plus importants. Les caractères étudiés sont relatifs soit au développement végétatif, soit à la phase de reproduction. L'analyse diallèle a été réalisée par 2 méthodes d'analyse : Griffing et Hayman. Comme pour la plupart des légumineuses autogames, les caractères végétatifs et la taille du grain présentent une hérédité essentiellement additive avec des effets dus à l'aptitude spécifique à la combinaison faibles (tableau III). Les héritabilités au sens large et au sens strict sont élevées. Les corrélations entre les valeurs d'aptitude générale à la combinaison et les valeurs propres sont élevées, la valeur phénotypique des parents donne donc une bonne idée de leur comportement en croisement (tableau III). L'analyse des diagrammes de Hayman (fig 3) montre la possibilité de transgressions sur les principaux caractères étudiés à l'exception de la précocité, et la présence vraisemblable d'épistasie pour la nouaison. Pour les caractères de nouaison, les héritabilités sont plus faibles, en raison d'une sensibilité accrue au milieu. Un hétérosis a été observé pour le rendement qui pourrait être lié aux faibles densités de culture utilisées et à la possibilité d'homéostase des hybrides. La création d'hybrides pourrait être une voie pour l'amélioration de la stabilité du rendement, même si aucune stérilité mâle ne permet d'envisager à ce jour cette voie. Dans le but actuel de création de variétés lignées pures, l'étude diallèle permet de préciser les parents potentiellement intéressants. Lublanc et $L A$ 123 sont des géniteurs intéressants pour la recherche de types précoces à bonne nouaison. Pour l'ensemble des caractères de rendement, Lucky est un géniteur de choix en particulier pour la nouaison et le poids de mille grains.

Lupinus albus $L=$ lupin blanc / diallèle / analyse génétique / amélioration / composantes du rendement / précocité / morphologie

* Correspondence and reprints 


\section{INTRODUCTION}

The white lupin (Lupinus albus $L$ ) is an annual grain legume of the family Papillonaceae. Its large seeds have a high protein (between 35$45 \%$ according to the genotype) and a high oil content (between $8-15 \%$ according to the genotype). The species is mainly self-pollinating. The residual outcrossing rate due to bumble-bees is estimated to be $10 \%$. The breeding of the species has mainly focussed on the creation of pure line varieties.

Most of the available genetic variability comes from traditionally cultivated populations collected around the Mediterranean (Gladstones, 1984). A wild subspecies ( $L$ albus ssp graecus) constitutes the rest of the variability which can be included in the breeding schemes.

The studies of Simpson (1984), Simpson and Neves-Martins (1984), Mota (1984) and Papineau (1987) have shown that a large range of morphological and physiological variability is available for breeding both in spring and winter lupins. In order to optimise this diversity, it is important to study the inheritance of the characters, ie their heritability and the importance of the different genetic effects.

This paper presents the results of a diallel analysis in spring white lupins where morphological characters and yield components were studied.

\section{MATERIALS AND METHODS}

The diallel mating design involved 7 genotypes, each representing a group of variations defined by Simpson and Neves-Martins (1984) (table I). Among these genotypes, there was a wide range of variation for all the characters under study that were related either to vegetative development or to yield. The different characters are listed in table II. The parents of the diallel were described by principal component analysis (PCA). The different genotypes could then be located in the range of variation for the different types of character and compared to each other. This analysis also allowed typology of the parameters by study of the correlation matrix.

Analysis of the correlations regarding parents and $F_{1}$ progenies allowed a grouping of the variates and consequently a reduction of the characters for genetic analysis of the diallel. Thus, the analysis presented in the present paper has focussed on the 6 following characters, each one supplying information on one aspect of plant development: flowering time of the primary inflorescence (in ${ }^{\circ} \mathrm{C} D$ since sowing with a basis of $4{ }^{\circ} \mathrm{C}$ ); length of the second primary branch; length of the central leaflet of the last but one leaf of the main stem; number of pods on the first 2 levels; thousand seed weight; yield.

The experimental design was a complete diallel including the reciprocals and the 7 selfed parental lines. Crosses were made during spring 1988 . The set of the $49 \mathrm{~F}_{1}$ and parents was sown in March 1989 in 2 replicates of 20 plants each. Cropping density was very low (7 plants $/ \mathrm{m}^{2}$ ) so that plants could express their potential in the absence of competition.

Two analysis methods (fixed models) were used: the method presented by Griffing (1956) gives an accurate estimate of combining abilities; the method de-

Table I. Origins and characteristics of the different lines involved in the diallel cross.

Genotypes Origins $\begin{gathered}\text { Earliness Alcaloids } \\ \text { of flowering }\end{gathered}$

\begin{tabular}{llll}
\hline TR1+ & Turkish ecotype & ++ & + \\
Lublanc & French variety & ++ & - \\
LA338 & Sudanese ecotype & + & ++ \\
LA123 & Moroccan variety & + & - \\
Lucky & French variety & -- & - \\
GR40 & Greek ecotype & -- & ++ \\
ITA2 & Italian ecotype & -- & + \\
\hline
\end{tabular}

Table II. Different characters analysed and their abbreviations.

No Character analysed

\begin{tabular}{ll}
1 & Number of leaves per main stem \\
2 & Flowering time of main stem $\left({ }^{\circ} \mathrm{CD}\right)$ \\
3 & Flowering time of branches $\left({ }^{\circ} \mathrm{CD}\right)$ \\
4 & Margin between flowerings $\left({ }^{\circ} \mathrm{CD}\right)$ \\
5 & Height of the main inflorescence $(\mathrm{cm})$ \\
6 & Number of primary branches \\
7 & Length of the second primary branch $(\mathrm{cm})$ \\
8 & Number of leaves per branch \\
9 & Plant habit $(7) /(5)$ \\
10 & Number of leaflets/leaf \\
11 & Length of the central leaflet $(\mathrm{cm})$ \\
12 & Width of the central leaflet $(\mathrm{cm})$ \\
13 & Central leaflet shape $(12) /(11)$ \\
14 & Total leaf surface (cm $\left.{ }^{2}\right)$ \\
15 & Number of pods per main stem \\
16 & Number of pods on the primary branches \\
17 & Number of pods on the stem \\
18 & and the primary branches \\
19 & Number of seeds per pod \\
20 & Weight of seeds per pod $(\mathrm{g})$ \\
21 & Weight of pods walls per seed weight \\
22 & 1 OoO seed weight $(\mathrm{g})$ \\
\hline
\end{tabular}


veloped by Hayman (1954) gives a more qualitative estimate of the inheritance of a character and also helps to determine the ability of a cross to surpass the parental range (Mather and Jinks, 1971). To use this method, 6 different hypotheses must be fulfilled : 1) normal diploid segregation; 2) no difference between reciprocal crosses; 3 ) independent action of non-allelic genes; 4) no multiple allelism; 5) homozygous parents; 6) genes independently distributed between the parents.

The non-respect of these hypotheses, mainly of hypotheses (3) and (6), can introduce biases into the analysis (Feyt, 1976).

\section{RESULTS}

\section{Description of the parents}

The parents were characterized through principal component analysis (PCA). The first axis of the $\mathrm{PCA}$ represented the larger source of variation among the set of parents. Axis 1 of the analysis accounted for the variation in vegetative characters (height, leaf area) and earliness of flowering. Fifty-one percent of the total variance was explained by the first axis. Axis 2 (12\% of the total variance) accounted for characters related to yield, eg the numbers of pods, and the number of seeds per pod.

Diagram 1-2 of this PCA presents a synthetic image of the variation involved in the diallel (fig 1). It also shows the specificity of each parent:

- the Turkish parent is very early and has a poor pod set. This induces the production of numerous upper branches;

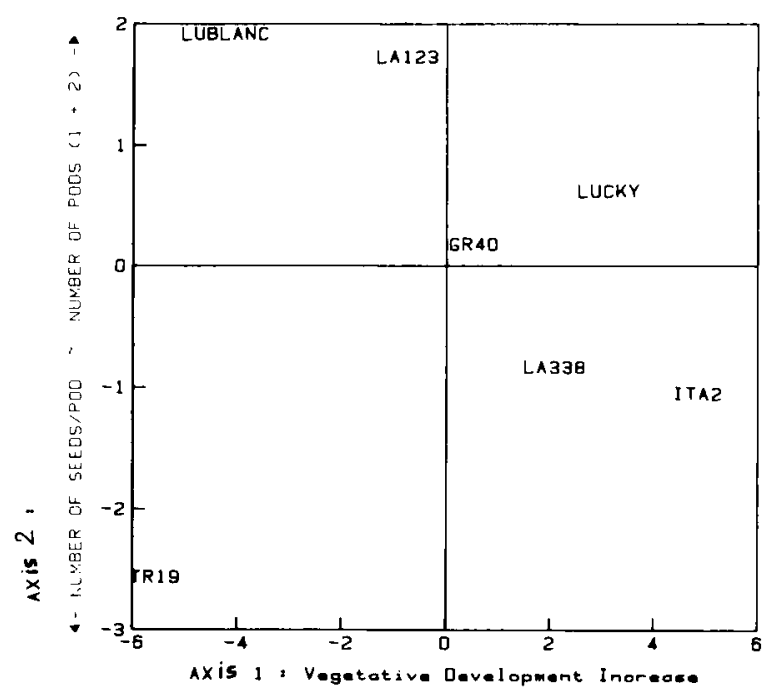

Fig 1. Relationships between the parents as shown by the diagram 1-2 of the principal component analysis.
- Lublanc, a sweet variety bred in France, is short, early with a good pod set and small seeds;

- the line originating from the Sudan has long internodes;

- the sweet line originating from Morocco, LA123 is rather early with large seeds;

- Lucky is a sweet variety with a late flowering, important vegetative development, a good pod set and large seeds;

- the Greek parent has bushy growth, an average vegetative development and a good pod set;

- the Italian line is very late with an extreme vegetative development, large seeds and a poor pod set.

\section{Character analysis}

The study of the relationship between the variates provided information on the physiology of the characters under study and the associations of characters which were met in the set of parents. Analysis of the correlation circles helped to defined groups of variates. Six groups were defined as follows: Group 1: the characters related to earliness of flowering; flowering times on the first 2 levels, number of leaves on the main stem and height of the primary inflorescence; Group 2: related to the first group: the characters of vegetative development; leaf characteristics, development of the branches; Group 3: measurement of pod setting. The pod set on a branch appeared correlated to the development of the organ for the material under study and the husbandry techniques of this experiment; for instance, thick stems with numerous leaves set high numbers of pods; Group 4: the characters related to seed and pod size; Group 5: the number of seeds per pod. In the last group, the yield and the number of pods per secondary branch appeared completely distinct from the previous ones. The analysis focussed on 6 variates, ie one from each group.

\section{Genetic analysis}

Variance analysis via the Griffing method showed the importance of the reciprocal effect and the combining abilities (table III).

The general combining ability (GCA) is the average of the gametic effect of a genotype for the 
Table III. Means, broad and narrow senses heritabilities, and different diallel analysis components (Griffing and Hayman) for the different characters studied.

\begin{tabular}{|c|c|c|c|c|c|c|}
\hline \multirow[t]{2}{*}{ Components } & \multirow[b]{2}{*}{1} & \multirow[b]{2}{*}{2} & \multicolumn{2}{|c|}{ Characters } & \multirow[b]{2}{*}{5} & \multirow[b]{2}{*}{6} \\
\hline & & & 3 & 4 & & \\
\hline \multicolumn{7}{|l|}{ Values } \\
\hline Mean & 513.64 & 6.78 & 7.644 & 31.59 & 433.65 & 52.92 \\
\hline Min & 448.33 & 4.57 & 5.606 & 16.73 & 319.29 & 25.38 \\
\hline Max & 612.69 & 8.64 & 9.278 & 45.58 & 535.15 & 77.03 \\
\hline \multicolumn{7}{|l|}{ Heritabilities } \\
\hline Broad sense & 0.938 & 0.890 & 0.861 & 0.589 & 0.762 & 0.449 \\
\hline Narrow sense & 0.858 & 0.778 & 0.748 & 0.504 & 0.688 & 0.307 \\
\hline (Mather and Jinks, 1971) & & & & & & \\
\hline \multicolumn{7}{|c|}{ Variance components (in \% of the total variance) } \\
\hline GCA & 81.6 & 62.7 & 73.5 & 40.7 & 64.9 & 25.0 \\
\hline SCA & 10.5 & 8.0 & 5.9 & 19.4 & 17.6 & 27.9 \\
\hline Rec effect & 2.0 & 11.8 & 9.1 & 6.0 & 2.2 & 11.9 \\
\hline \multicolumn{7}{|c|}{ Correlation GCA-mean parent } \\
\hline & 0.981 & 0.961 & 0.974 & 0.828 & 0.928 & 0.886 \\
\hline \multicolumn{7}{|l|}{ Heterosis } \\
\hline Dominance sense & negative & negative & negative & positive & positive & positive \\
\hline$\%$ (mean parent) & -4.31 & 0.32 & 1.05 & 14.76 & 8.85 & 31.80 \\
\hline$\%$ (sup parent) & -13.82 & -18.64 & -14.64 & -3.88 & -7.34 & 3.17 \\
\hline
\end{tabular}

GCA = general combining ability; SCA = specific combining ability; Rec effect : reciprocal effect. Character No $1:$ flowering time of the main stem $\left({ }^{\circ} \mathrm{CD}\right)$; Character No 2 : Number of leaves per branch; Character No $3:$ length of the central leaflet $(\mathrm{cm}) ;$ Character No 4 : number of pods on the stem and the primary branches; Character No $5: 1000$ seed weight (g); Character No $6:$ yield (q/ha).

character under study. The GCA were prevalent for all characters, and above all for the vegetative characters for which they represented up to $81 \%$ of the total variance for flowering time. Consequently, these characters, and to a lesser extent the reproductive characters, showed a mainly additive inheritance.

The specific combining ability (SCA) only accounted for a small part of the total variance for the vegetative traits. This part increased for the numbers of pods, especially on the upper branches. The SCA became prevalent for yield only. This will be discussed later in this paper.

All the correlations between the GCA and phenotypic value of the parents for the different characters were highly significant $(P>0.01)$ even for the characters where the SCA proved to be important. Using the GCA of the parents for all the characters, cluster analysis was made in order to study the relationships between the parents in terms of gametic effects (fig 2).
The Hayman analysis for 3 typical variates is shown (diagrams I and II of the Hayman analysis: fig 3). For all the characters, the slopes of the regression $\mathrm{Wr} / \mathrm{Vr}$ were not significantly different from 1 . The only exception was for the number of pods on the first 2 levels. This suggests possible epistasis for pod setting. The parent distribution in Hayman's diagram I suggested high

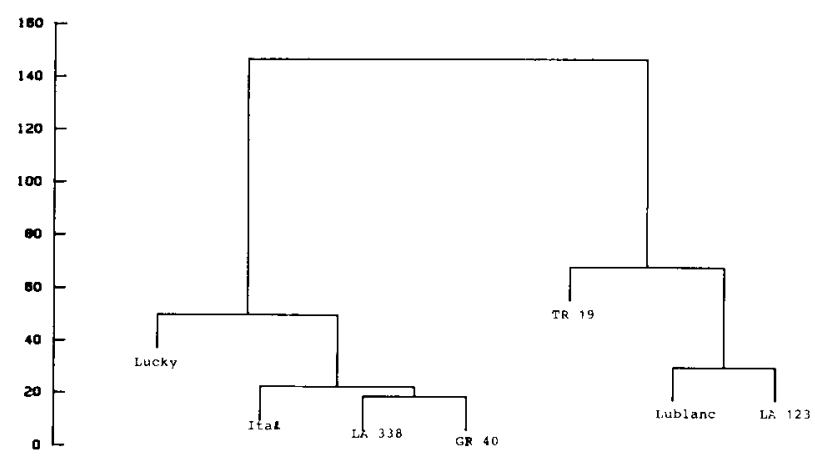

Fig 2. Dendrogram between parents on GCA values. 

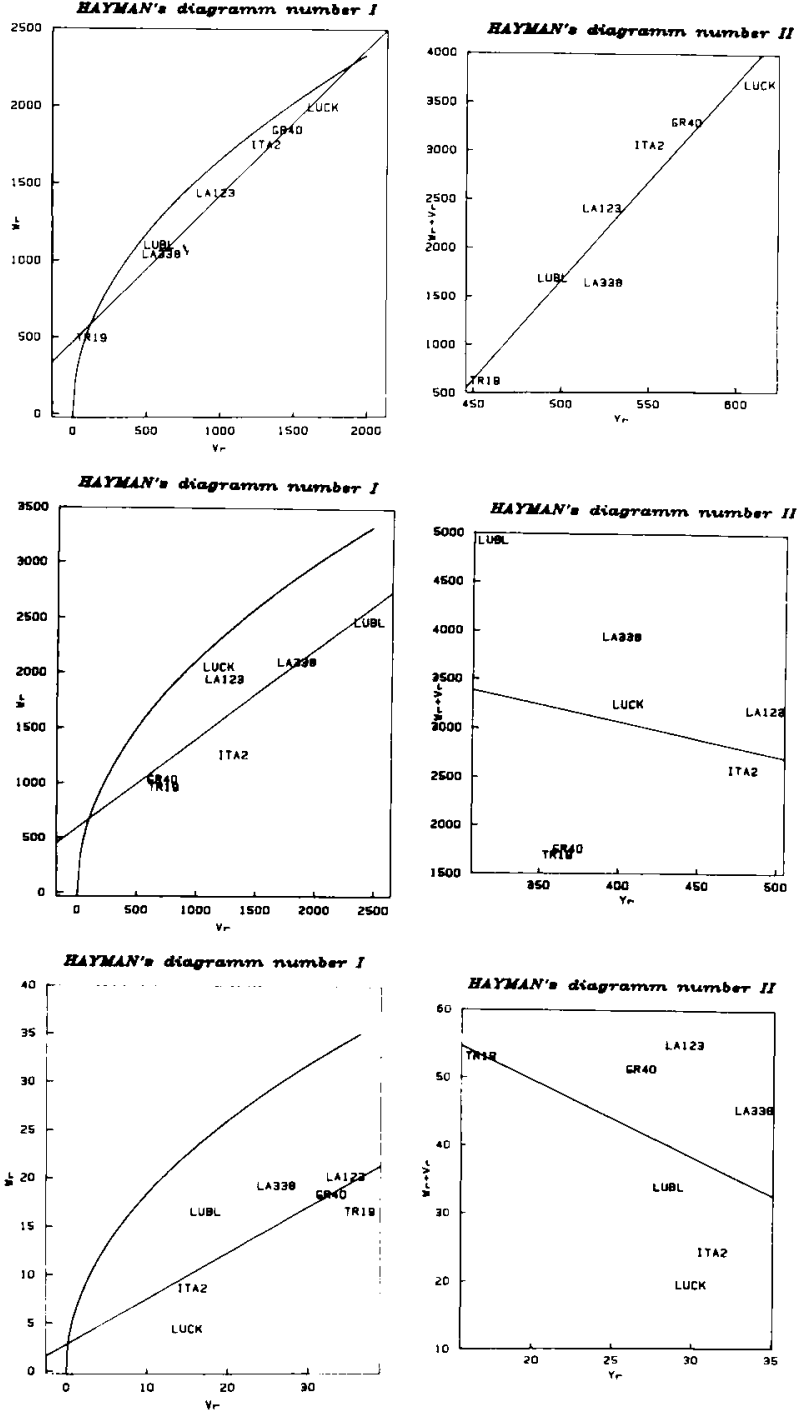

Fig 3. Hayman's diagrams for some of the characters studied. Character 1: Flowering time on the main stem. Character 2: 1000 seed weight. Character 3: Pods (stem + primary branches).

transgression possibilities except for earliness, TR19 being the earlier genotype available among the spring type white lupins.

As shown by the Griffing analysis, inheritance shows an incomplete dominance which tends towards a total additivity for the vegetative characters, represented here by the flowering time of the main stem. The effect of dominance is shown in diagram II : if dominance has a negative effect, the genotypes with recessive alleles will show higher values for character. For the white lupin, it was the case for dominance which can be seen for the flowering time; if dominance has a positive effect, genotypes with dominant alleles will show higher values. This appeared for the reproductive traits like seed size or pod setting. The importance of the different genetic effects will be studied in the 6 characters chosen.

\section{Flowering time of the primary inflorescence}

This character mainly depends upon the vernalization requirements of the genotype. Vernalization requirements, even reduced, do exist among the spring type lupin. The less vernalization requirement a genotype has, the earlier it will flower. This character was highly heritable, both in a broad and in a narrow sense. The inheritance was mainly additive even if, as shown by the analysis of variance, the reciprocal and non-additive effects were significant. Incomplete dominance was in favour of earliness. The correlation between GCA and phenotypic values of the parents was high. The GCA of the genotypes can be estimated from their phenotype.

\section{Number of leaves on the primary branches}

The number of leaves on a branch determines the flowering time of this organ. This character is of a great importance in controlling plant architecture. Heritability was high $(0.89)$ this character being non sensitive to environmental conditions, for instance density. It was mainly governed by additive effects but reciprocal effects were also significant. There were no SCA effects. As regards flowering time, the GCAphenotype value correlation was high.

\section{Length of the central leaflet}

As for most of the vegetative characters, this one was also highly heritable with a mainly additive inheritance. Reciprocal effects were also significant. The GCA/SCA ratio was very high and confirmed the prevalence of additivity. Dominance was in favour of a reduction in the length of the central leaflet.

\section{Number of pods on the first 2 levels}

This character combines information from 2 different characters: the number of pods on the primary inflorescence which behaved in this experiment as a vegetative character (high heritability, additive heredity) and the number of pods on the secondary inflorescence. This one had a low heritability $(0.36)$ and although the additive effects were still prevalent, the non-additive effects were important. Dominance was in favor of an increased number of pods. The number of pods showed both important additive and non-additive effects. The GCA-phenotype value correlation was low. 


\section{Thousand seed weight}

This character showed the same trend as the vegetative character: high heritability $(0.76)$ and a mainly additive inheritance. However, the SCA effects were significant and there was no reciprocal effect. Dominance was for an increased seed size.

\section{Yield}

Yield had a low heritability $(0.44)$ due to high susceptibility to environmental variations. The additive (GCA) and non-additive (SCA) effects were nearly equivalent. Dominance was for a higher yield. An average heterotic effect of $+31.8 \%$ over the mean parent and $+3 \%$ over the best parent was measured.

\section{DISCUSSION}

The genetics of the analysed characters is related to the studied genotypes and experimental conditions. Its generalization to other lines and other environments is possible if undertaken with caution.

Significant reciprocal effects were observed in all the vegetative characters. This could be due to the size of the $F_{1}$ seeds sown. It could influence the quality of crop setting and vigor of seedlings and interfere with the phyllochrones. The seeds originating from crosses mainly depend upon the mother plant and there were large differences in seed size between some reciprocals. This assumption is confirmed by the relationship between the differences between reciprocals for the size of the $F_{1}$ seeds sown and the differences between reciprocals for various morphological characters. Figure 4 shows this relationship when the height of the main stem was considered. The correlation coefficient $(0.56)$ between the 2 characters was highly significant. An increase in sown seed size led to a higher main stem and a more vigorous plant.

Similar relationships have been reported in various species like tobacco, common vetch, alfalfa, Lolium perenne, and have been reviewed by Roach and Wulff (1987). The presence of reciprocal effects biased the Hayman analysis and the calculation of narrow sense heritability. However, reciprocal effects always accounted for $<9 \%$ of the total variance. Consequently, the results of these 2 procedures can be us ed but with care.
The vegetative characters showed a mainly additive heredity, variance due to GCA effects accounting for $>80 \%$ of the total variance. This situation was commonly met among the autogamous species and especially the legume species. Dickinson (1967) and Nienhuis and Singh (1986) reported the prevalence of additive variance on vegetative parameters in Phaseolus vulgaris L, a small heterosis was also observed. Spagnoletti-Zeuli et al (1985) also showed the importance of additive effects on vegetative characters in Triticum durum $\mathrm{L}$.

The high correlations between the GCA and phenotypic value of the parents for most characters is of great importance for lupin breeding. This situation has also been reported in other autogamous species, eg Spagnoletti-Zeuli et al (1985) in Triticum durum $L$ and in partly open pollinated crops eg the study of de Pace et al (1988) on Vicia faba. This situation, associated with high broad sense and narrow sense heritabilities encountered in lupins indicates that early selection of spaced plants and pure-line breeding should be successful for vegetative characters. The parents could be chosen according to their phenotype and screening in the progenies during the first generations should be adequate.

However, the selection pressure on this type of character should be moderate in order to avoid quick erosion of genetic variability for the reproductive characters. Indeed, these characters showed a less significant additivity. The pod set and the number of seeds per pod also showed a reduced correlation between the GCA and phenotypic value. Appropriate mating design should be set for a better estimation of the GCA of the parents. Seed size behaviour was close to that of the vegetative characters. Because of this fact and its correlation with the yield, van der Mey (1989) reported a correlation of 0.521 between these 2 characters; it is a potentially interesting selection criterion.

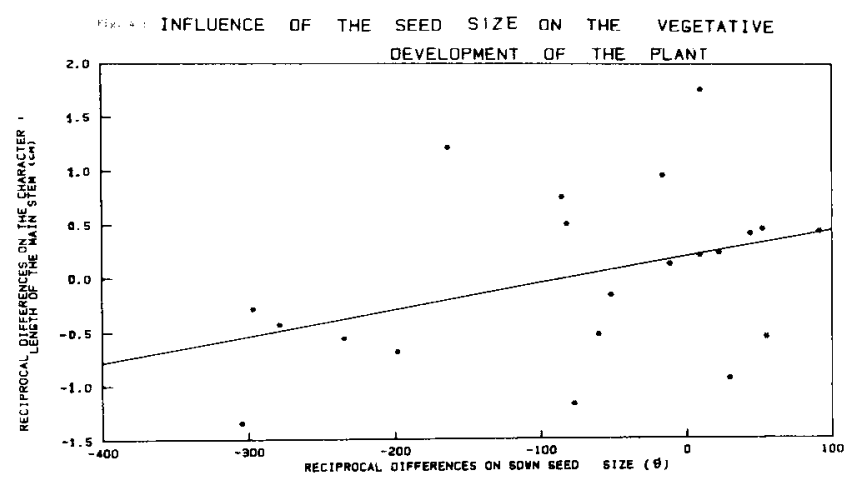

Fig 4. Influence of the seed size on the vegetative development of the plant. 
Yield was the only character where variance due to the SCA effect was larger than that due to the GCA effect. Heterosis was observed for this character, and this appeared important for the early hybrids $(+57.2 \%$ and $+27.1 \%$ over the mean parent for the early and late hybrids respectively). A hybrid was considered as early if it flowered earlier than the average. This could be explained by a hybrid vigor which allowed the hybrid plants to set extra pod levels on the early types. It is clearly shown when the relation between the calculated yield (number of plants $/ \mathrm{m}^{2} \mathrm{x}$ number of pods on the first 2 levels $x$ number of seeds per pod $x 1$ seed weight) and the observed yield is analysed (fig 5). The correlation is rather low and it is mainly the early hybrids which are far from the line $y=x$ while most of the early parents are close to it. This is due to extra level of pods on the early hybrids. It appeared as a homeostasis and yield stability factor in the context of a high yield level in spite of the low seeding densities. If the production of hybrid seeds was easy, the $F_{1}$ hybrids would be more interesting for yield stability improvement than for direct yield improvement. However, no male sterility is presently available for such a production. Nevertheless, these results should be handled with care because of the seeding rate in this experiment. Indeed, it is likely that an increase in density might reduce the heterotic effects and modify the classification of the genotypes. Such influences of density do not affect the vegetative traits which, apart from the stem and branch length, are determined very early in the cycle when no interplant competition exists.

The study of the dendrogram obtained from the GCA shows the similarity of the parents for their average gametic effect. Lublanc and LA123

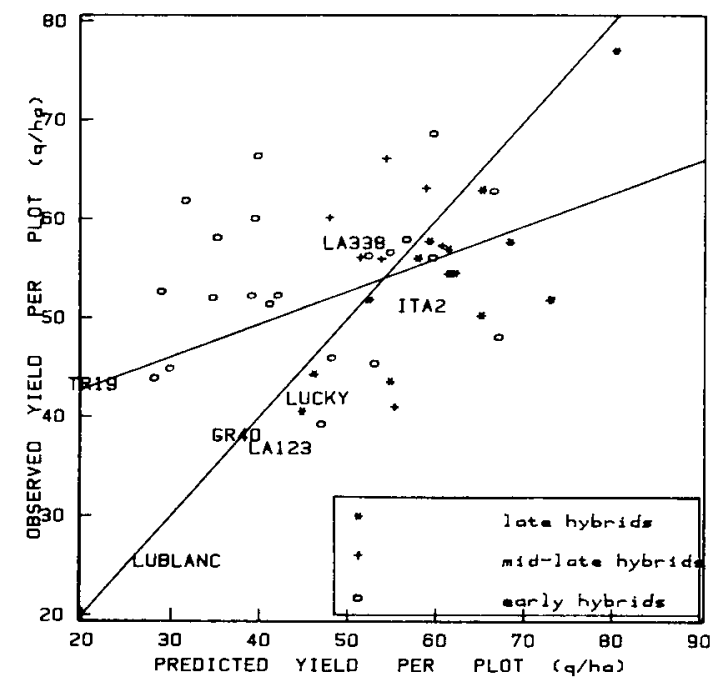

Fig 5. Comparison observed yield-predicted yield. seem very close. They gave an interesting earliness of flowering to their progenies. TR19, close to this group because of its vegetative characters and its earliness, was slightly detached because of its poor pod set.

The other group on the dendrogram contains the later and more vigorous genotypes. LA338 and GR40 are very close to these characters. ITA2 and Lucky also belong to this group although Lucky, due to the reproductive characteristics of its progenies, is different.

From the GCA values, Lublanc, LA123 and TR19 appeared as first-choice parents for an earlier flowering time. However, the low pod set GCA value of TR19 reduced its potential. For the reproductive characters, Lucky appeared as an interesting progenitor for pod setting and to a lesser extent for seed size.

This study showed that the spring white lupin behaves as most of the autogamous legumes, ie characters with a mainly additive heredity, high correlations between GCA and phenotypic values, and reduced SCA. This information can help to define characters which are important for breeding. The flowering time or the length of the main stem provide valuable information on vegetative development. They are highly heritable and simple to measure. Among the reproductive characters, seed size, measured by thousand seed weight, is the most heritable. The other significant yield components, number of pods and number of seeds per pod are important for breeding. Their heritabilities are lower due to a higher susceptibility to the environment and to a heredity with more dominance. However, effective breeding is possible. Mating designs for an accurate measurement of the GCA of the possible parental lines would be helpful. White lupin breeding is presently creating pure-line varieties. In this context, it is important to predict the range of pure lines which can be selected from a single cross. This prediction is based on the concept of the lines-value defined by Gallais (1979) but also on the interline variance. Thus, it is possible to determine the percentage of transgressive lines. Additive heredity is an important prerequisite for numerous transgressions. As shown in this study, most of the white lupin characters are governed by additive heredity; it is consequently a major asset for lupin breeding.

\section{REFERENCES}

Dickinson MH (1967) Diallel analysis of seven economic characters in shap beans. Crop Sci 7, 121 124 
Feyt $H$ (1976) Étude critique de l'analyse des croisements diallèle au moyen de la simulation. Ann Amélior Plant 1976, 26, 173-193

Gallais A (1979) Le concept de valeur en lignées et son utilisation possible en sélection. Ann Amélior Plant 29, 1-22

Gladstones JS (1984) Present situation and potential of Mediterranean African lupins for crop production. Proc 3rd Int Lupin Conf, La Rochelle, 4-8 June 1984, 17-37

Griffing G (1956) Concept of general and specific combining ability in relation to diallel crossing systems. Aust J Biol Sci 9, 463-493

Hayman BI (1954) The theory and analysis of diallel cross. Genetics 39, 789-809

Mather K, Jinks JL (1971) Diallel. In: Biometrical Genetics. Chapman and Hall, London, 249-284

van der Mey JAM, Middel J, Mc Donald A (1989) An analysis of yield components of Lupinus albus $\mathrm{L}$. S Afr J Plant Soil 6(3), 171-175

Mota N (1984) Lupin germplasm resources in Portugal. Proc 3rd Int Lupin Conf, La Rochelle, 4-8 June 1984, 104-107
Nienhuis JR, Singh PS (1986) Combining ability analysis and relationships among yield, yield components, and architectural traits in dry bean. Crop Sci $26,21-27$

de Pace C, Filipetti A, Ricciardi L (1988) A combined univariate and multivariate approach for selecting high performing genotypes of Vicia faba L. Plant Breeding 100, 199-208

Papineau J (1987) La résistance au froid des lupins blancs (Lupinus albus L). Variabilité génétique, sélection, création de matériel végétal doux. Diplôme ingénieur DPE ENSAM, $67 p$

Roach DA, Wulff RD (1987) Maternal effects in plants. Ann Rev Ecol Syst 18, 209-235

Simpson MJA (1984) Geographical variation in Lupinus albus L. I. Iberia. Z Pflanzenzuecht 96, 241-251

Simpson MJA, Neves-Martins JM (1984) Distribution of plant types in Lupinus albus L. Proc 3rd Int Lupin Conf, La Rochelle, 4-8 June 1984, 88-101

Spagnoletti-Zeuli PL, de Pace C, Porceddu E (1985) Variation in Durum wheat populations from different geographical origins. III. Assessment of genetic diversity for breeding purposes. Z Pflanzenzuecht 94 , 177-191 